\title{
Vegetative propagation of patagonian cypress, a vulnerable species from the subantarctic forest of South America
}

\author{
Propagación vegetativa del ciprés de la cordillera, una especie vulnerable \\ del bosque subantártico de Sudamérica
}

\author{
Alejandro Aparicio ${ }^{a *}$, Mario Pastorino ${ }^{\mathrm{a}, \mathrm{b}}$, Alejandro Martinez-Meier ${ }^{\mathrm{a}}$, Leonardo Gallo ${ }^{\mathrm{a}}$

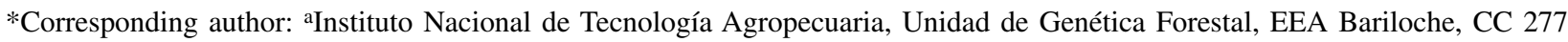 \\ (8400) Bariloche, Río Negro, Argentina, tel.: +54 02944 422731, fax: +54 02944 424991, aaparicio@bariloche.inta.gov.ar \\ bCONICET, Consejo Nacional de Investigaciones Científicas y Técnicas, Argentina.
}

\begin{abstract}
SUMMARY
Increasing risks of loosing forest genetic resources and the need for a sustainable quality wood supply make focusing research efforts on undomesticated tree species necessary. The study of their genetic variation in vegetative propagation ability and the development of practical methodologies to obtain genetic copies are essential tools for conservation and breeding programs. patagonian cypress Austrocedrus chilensis is a vulnerable conifer native to the subantarctic forest of South America, with high ecological importance and economical potential. Its genetic diversity, mostly sheltered within unprotected populations, is seriously threatened. This work examined the ability of different genotypes of A. chilensis from xeric, mesic and humid populations to propagate asexually by stem rooting and scion grafting. The influence of exogenous auxins, season of cutting collection, ontogenetic stage of the donor plants, grafting season, and type of scions, was analyzed. Stem rooting ability was found to be poor both for adult (average $=0.27 \%)$ and juvenile ortets (average $=2.10 \%$ ). Only one treatment, a juvenile progeny from a xeric provenance, showed remarkable results with $33.33 \%$ of rooting capacity. Grafting showed good results in early spring experiment using vigorous semi-hardwood scions, with an average of $80.95 \%$ of successful grafts. Compatibility between genotypes from different provenances used as scion and rootstock was found to be wide. These results indicate that although A. chilensis is a difficult-to-root species, its vegetative propagation by means of scion grafting is feasible using low cost technology.
\end{abstract}

Key words: Austrocedrus, Cupressaceae, stem rooting, scion grafting.

\section{RESUMEN}

Los crecientes riesgos de pérdida de recursos genéticos forestales y la necesidad de una producción sostenible de madera de calidad hacen necesario orientar la investigación hacia especies arbóreas nativas no domesticadas. Para rescatar la diversidad genética amenazada y como una importante herramienta para el mejoramiento genético, resulta necesario estudiar la capacidad de las especies para propagarse vegetativamente, así como desarrollar técnicas para obtener copias genéticas. El ciprés de la cordillera (Austrocedrus chilensis) es una conífera vulnerable del bosque subantártico de Sudamérica, de gran importancia ecológica y potencial económico. $\mathrm{Su}$ diversidad genética se encuentra seriamente amenazada. En este trabajo se examinó la capacidad de diferentes genotipos de poblaciones xéricas, mésicas y húmedas de A. chilensis, para propagarse asexualmente por enraizado de estacas y por injertos. Se analizó además la influencia de auxinas exógenas, de la estación de colecta, del estadio ontogénico de las plantas donantes, de la estación de injerto y del tipo de púa. La capacidad de enraizado fue muy pobre, tanto para ortets adultos (promedio $=0,27 \%$ ) como para juveniles (promedio $=2,10 \%$ ). Sólo una progenie juvenil de procedencia xérica mostró resultados remarcables, con $33 \%$ de enraizado. Los injertos mostraron buenos resultados a comienzos de primavera usando esquejes vigorosos y semileñosos, con un $80,95 \%$ de prendimiento. La compatibilidad entre genotipos de diferentes procedencias usados como púa y portainjertos fue amplia. Estos resultados indican que aunque A. chilensis es una especie de difícil enraizado, su propagación por injertos es factible utilizando tecnología de bajo costo.

Palabras clave: Austrocedrus, Cupressaceae, enraizado de tallos, injertos.

\section{INTRODUCTION}

Vegetative propagation is an irreplaceable tool for tree domestication and breeding, and its advantages and implications have been widely treated in literature (Wright 1976, Zobel and Talbert 1984, Park et al. 1989). Although in forest research most of the efforts were traditionally focused on propagation of timber species, a scenario of rapid climate changes (IPCC 2008), with increasing land degradation and genetic diversity loss, makes it necessary to focus also on species that are important for other functions, such as support of ecosystems and supply of non-timber 
products, or have a remarkable potential for quality wood production. Programs involving indigenous species and impoverished communities have become important in the last decades (Leakey et al. 2005) and the development of low cost vegetative propagation technologies is one of its most relevant aspects (e.g. Tchoundjeu et al. 2004, Atangana et al. 2006). Despite the advances in tissue culture, for many conservation, domestication and breeding programs, lower cost macro-propagation methods continue to be the most convenient approaches even when human and financial resources were not scarce (e.g. Wollemia nobilis J. H. et Allen program, Wollemi Pine International 2004).

Only a few tree species native to the subantarctic forests of South America are included in domestication and conservation programs, being several species of Nothofagus spp. among the most relevant (Donoso and Gallo 2004). In the Argentinean Patagonian region, patagonian cypress Austrocedrus chilensis (D. Don) Pic. Ser. et Bizzarri (Cupressaceae) is one of the most important native tree species because of its ample geographic distribution, its ecological and multi-purpose functions and its potential timber value. It ranges through a wide variation in ecological conditions, regarding latitude, altitude, soils and pluviometric regime (Gallo et al. 2004), which suggests a large phenotypic plasticity. Its adaptation to extreme xeric conditions makes it a suitable species for commercial forestry in arid environments. Its wood has been widely used in the region during all the last century due to its good technological quality and beautiful design. Even without forest management and genetic improvement, $A$. chilensis wood is the most valuable among the conifers in Argentina (SAGPyA 2008). The remaining total cover area of A. chilensis has been measured in 142,000 ha (Bran et al. 2002), from an estimated original of about two million (Schmaltz 1992), being the species categorized as vulnerable (Conifer Specialist Group 1998). The total of the wood of A. chilensis consumed in the region still comes from natural stands, and an increasing demand exists for seedlings for commercial plantations and restoration purposes. For these reasons, a domestication and conservation program has been recently initiated at the Instituto Nacional de Tecnología Agropecuaria, Bariloche.

In Argentina, the distribution of A. chilensis corresponds to a Mediterranean-like climate with a tendency to a moderate to severe aridity. One remarkable environmental gradient given by the precipitations regime molds the physiognomy of A. chilensis forests that grow along a narrow strip bordering the Cordillera de Los Andes, from $37^{\circ} 07^{\prime}$ to $43^{\circ} 44^{\prime} \mathrm{S}$ (Pastorino et al. 2006). Across this strip, in a west-east direction, mean annual precipitation (m.a.p.) ranges from ca. 3,000 to less than $400 \mathrm{~mm}$. This extremely abrupt gradient determines the occurrence of drastic changes in vegetation in distances not larger than $100 \mathrm{~km}$, being five A. chilensis forest types recognized (Gallo et al. 2004). The most xeric populations (extrememarginal forest type), consisting of small isolated patches located into the patagonian steppe, were found to be the most genetically diverse (Pastorino 2001, Pastorino et al. 2004). Despite the evolutionary and adaptive relevance of these xeric extreme-marginal populations, they still lack of any national or international legal protection policy. Their location in private lands, the extreme environmental conditions in which they grow, their reduced number of individuals, and a context of rapid climate changes threaten the genetic diversity they shelter, as well as their dynamic evolutionary processes, being the rescue and ex situ in vivo conservation of endangered genotypes, or even entire populations, necessary. These extreme marginal populations have to be included in research works oriented to study adaptive traits, such as vegetative propagation capacity.

Although some isolated attempts have been made to asexually propagate A. chilensis (Gómez Hernández 1994) or have been mentioned in literature (Matínez Crovetto 1948, Havrylenko 1965, Hechenleitner et al. 2005), not enough scientific and systematic research has been developed in order to elucidate the genetic, physiological, and ecological factors involved in macro-propagation processes, such as stem rooting or scion grafting. Currently, a clear vegetative propagation protocol does not exist.

Several adaptive and ecological characteristics of $A$. chilensis suggest that its natural rooting ability would be poor. As most conifers, it has no adaptations to asexually persist after severe disturbances, such as preformed root initials, allowing rooting of dislodged stems, or the ability of sprouting from stumps or roots. Although with fluctuations in time, A. chilensis produces large seed outputs with high viability (Donoso et al. 2006) propagating efficiently by sexual means, even in the adverse xeric limits of its distribution. Nevertheless, adventitious roots formation eventually occurs in natural populations. Compact groups of apparently individual trees, more frequently observed in the xeric marginal populations, have been found to be clones (multi-stemmed phenotypes) formed by branch layering (Pastorino and Gallo 1997, Gallo et al. 2004). This natural process is probably a good signal for the success of artificial vegetative propagation by stem rooting, although it could be strongly dependent on the genotype.

The genetic entity at different levels (i.e. provenance, family, individual) is largely relevant in determining the rooting behavior within a species (Ying and Bagley 1977, Greenwood and Weir 1994, Dick et al. 1996, Stankova and Panetsos 1997, Shoemake et al. 2004). As an example, individual differences in the rooting capacity of Cupressus sempervirens $\mathrm{L}$. ranged from 7 to $81 \%$ for one same set of experimental conditions (Stankova and Panetsos 1997). Therefore, it has to be considered that the propagation protocol to be used in breeding and conservation programs could be not unique within a species. Grafting techniques are useful when difficulties are found to propagate trees by stem rooting, being also the success of grafting strongly dependent on an intrinsic genetic capacity, and on the compatibility between genotypes (Copes 1999, Hartmann et al. 
2002). Besides the intrinsic genetic abilities, a multiplicity of environmental factors affects the success of both rooting and grafting processes in trees (e.g. ontogenetic stage, type of vegetative material, season of collection, hormonal treatments, propagation environment, techniques). Although general guidelines are provided in literature in relation to the most important environmental effects (Hartmann et al. 2002), the results when analyzing a particular group of plants (e.g. narrow-leaved evergreens) are species specific. As an example, stem cuttings of Chamaecyparis lawsoniana (A. Murr.) Parl. root better if collected during the dormant period (Zobel 1990), while Chamaecyparis thyoides L. roots easily during the activity period (Hinesley et al. 1994). In the case of A. chilensis, as a slow-growing and long-lived conifer, the main problem facing its vegetative propagation could be related to the ontogenetic stage of the donor plants. The most endangered and genetically variable populations consist mostly of mature and overmature trees, what a priori supposes a great disadvantage, particularly for stem rooting. Related to the ontogeny of plants, several characteristics of the vegetative material such as tissue consistence, physiological conditions, vigor and health, are major factors influencing both rooting and grafting processes (Hartmann et al. 2002).

The objective of this work was to comprehensively investigate 1) the genetic variation in rooting ability of $A$. chilensis, considering the influence of the season of cuttings collection, the ontogenetic stage of the donor plant, and the exogenous auxin supply; and 2) the grafting capacity and compatibility of different genetic origins of A. chilensis, under the influence of season and type of vegetative material. We report basic information to support future research works and to develop practical methodologies for conservation and domestication programs for A. chilensis.

\section{METHODS}

Propagation environment. Four stem rooting and three scion grafting trials were conducted in an experimental greenhouse, located at INTA (Instituto Nacional de Tecnología Agropecuaria), in San Carlos de Bariloche city (latitude: $41^{\circ} 07^{\prime} \mathrm{S}$, longitude: $71^{\circ} 15^{\prime} \mathrm{W}$, altitude: $810 \mathrm{~m}$ asl), Argentina. The greenhouse was equipped with intermittent mist, run four times per day during the maximum temperature hours. Relative air humidity inside the greenhouse was maintained between 55 and $95 \%$, while mean minimum and maximum temperatures were $10 \pm 3$ and $25.4 \pm 5^{\circ} \mathrm{C}$ in spring experiments, and $7 \pm 4$ and $25 \pm$ $5^{\circ} \mathrm{C}$ in late summer experiments. These last environmental parameters were relevant for the grafting experiments. For stem cuttings experiments, a rooting bed with bottom heat and a plastic tunnel was used. Bed substrate consisted of inert volcanic sand, kept at field capacity humidity level by means of sub-irrigation. Substrate temperature was regulated between 21 and $28^{\circ} \mathrm{C}$. Air humidity inside the tunnel was maintained between 75 and 100\%. In late spring and winter experiments the mean daily air temperature inside the propagation tunnel was $19 \pm 3^{\circ} \mathrm{C}$, while in summer and late summer it was $21.2 \pm 5^{\circ} \mathrm{C}$. Substrate was disinfected with soil fungicide before the installation of the experiments and a systemic fungicide was applied to the cuttings each 15 days.

Rooting of stem cuttings experiments. Rooting experiments were conducted at four different seasons: experiment 1) late spring, starting on 16 November; experiment 2) mid-summer, starting on 4 February; experiment 3) late summer, starting on $12 \mathrm{March}$; and experiment 4) late winter, starting on 18 August. Plot sizes were 8, 15, 8 and 10 respectively. Each experiment was finished after 60 days.

The adult donor trees (ortets) were selected within two contrasting provenances: 1) Cerro Otto (O), a mesic population, and 2) San Ramón (SR), a xeric population. The average ages of the sampled stands were $40 \pm 5$ and $100 \pm 20$ years respectively. In SR population, both single and multi-stemmed genotypes were selected. Cuttings were collected from partial reiterations from the lower parts of the crowns. Third order semi-hardwood stems of 7 to 9 $\mathrm{cm}$ long were prepared, leaving a remaining leaf area of ca. $5 \mathrm{~cm}^{2}$ in the distal extreme. Cuttings from juvenile individuals, corresponding to three xeric $(\mathrm{H}$ : Huinganco, M: El Maitén, P: Pilcañeu), one mesic (O) and one humid (B: Puerto Blest) provenance were collected from seedlings bred in our experimental nursery. Complete softwood or semi-hardwood second order stems were used. Size and leaf area were similar to those of the adult cuttings. Characteristics of both adult and juvenile ortets are summarized in table 1.

All four experiments were designed in order to evaluate the variation in rooting ability as a function of the genetic entity (treatment). Each plot corresponded to one replicate of each treatment. One different level of indole-3-butyric acid (IBA) alcoholic solution $(1,400 ; 2,800 ; 4,200 ; 5,600$ and $7,000 \mathrm{mg} \mathrm{L}^{-1}$ ) was randomly assigned to each plot corresponding to the adult genotypes in all the four experiments and to the juvenile treatments in experiment 4 . An additional 5,000 $\mathrm{mg} \mathrm{L}^{-1}$ IBA plot was included for all the treatments in experiment 4 , and for the adult genotypes and P12 juvenile progeny in experiment 2. Quick-dip method (Mesén 1998) was used to apply the auxin alcoholic solutions, with a five seconds immersion time. Additionally, two commercial products with $\alpha$-naphtalene acetic acid (NAA) $1,000 \mathrm{mg} \mathrm{L}^{-1}$ concentration (gel and powder) were applied to all the treatments in experiment 2, and to P12 juvenile progeny in experiment 4 . A control plot $(0 \mathrm{mg}$ $\mathrm{L}^{-1}$ auxin level) was included for each assayed genetic entity in all the four experiments.

Our experimental designs allow analyzing the response variable (percentage of rooting) using the linear random coefficient regression model (Littell et al. 2006) with the auxin level (IBA level) as the covariate. 
Table 1. Cuttings donor trees used in the rooting experiments.

Genotipos utilizados como dadores de estaquillas en los ensayos de enraizado.

\begin{tabular}{|c|c|c|c|c|c|}
\hline Denomination & Provenance & Ontogeny & Sex & Type of stem & Experiment \\
\hline SR1 & San Ramón & Adult & Female & Single & 1,3 \\
\hline $\mathrm{SR} 2$ & San Ramón & Adult & Male & Single & 1,3 \\
\hline SR3 & San Ramón & Adult & Male & Multi-stemmed & 1,3 \\
\hline SR4 & San Ramón & Adult & Male & Multi-stemmed & $1,2,3,4$ \\
\hline SR5 & San Ramón & Adult & Female & Multi-stemmed & $1,3,4$ \\
\hline SR6 & San Ramón & Adult & Female & Multi-stemmed & 1,3 \\
\hline $\mathrm{O} 1$ & Cerro Otto & Adult & Female & Single & $1,2,3,4$ \\
\hline $\mathrm{O} 2$ & Cerro Otto & Adult & Male & Single & $1,3,4$ \\
\hline $\mathrm{O} 4$ & Cerro Otto & Adult & Female & Single & $1,3,4$ \\
\hline P12 (progeny, 10 plants) & Pilcañeu & Juvenile & - & Multi-stemmed mother & 2,4 \\
\hline $\mathrm{O} 18$ & Cerro Otto & Juvenile & - & Single & 2 \\
\hline M10 (progeny, 14 plants) & El Maitén & Juvenile & - & Single mother & 2 \\
\hline H15 (progeny, 14 plants) & Huinganco & Juvenile & - & Single mother & 4 \\
\hline B (provenance, 10 plants) & Puerto Blest & Juvenile & - & Single mothers & 4 \\
\hline
\end{tabular}

Scions grafting experiments. Three different seasons were tried for grafting experiments: experiment 5) early spring, between 21 and 26 September; experiment 6) mid-spring, on 21 October; and experiment 7) late summer, between 7 and 14 March.

Completely exposed partial reiterations were collected of adult trees from the same two populations sampled for rooting experiments $(\mathrm{O}$ and $\mathrm{SR})$. The collected branches were conditioned in humid chamber at $4^{\circ} \mathrm{C}$, and grafts were practiced within 48 hours after the collections. Scions consisted of third order hardwood or semi-hardwood stems, of 4.5 to $6.5 \mathrm{~mm}$ in diameter, 12 to $15 \mathrm{~cm}$ in length, and a remaining leaf area of about $40 \mathrm{~cm}^{2}$ in the distal third. They were classified according to stem and foliage tissues consistence and vigor: type 1) hardwood stems, with small hard and compact foliage; type 2) semi-hardwood stems, with remarkable growth from the current season; and type 3) semi-herbaceous shoots, with long vigorous internodes from the current year and big leaves. Characteristics of scions donors are shown in table 2.

In experiments 5 and 7, three secions (replicates) from each donor genotype were assayed $(\mathrm{N}=42)$. Each genotype was grafted over three seedlings (rootstock) corresponding each one to humid, mesic and xeric provenances: 1) Puerto Blest; 2) Cerro Leones (CL); and 3) Pilcañeu. Rootstock consisted of three to six year old seedlings, with a mean height of $50 \pm 10 \mathrm{~cm}$. In spring trials, they were conditioned inside the greenhouse 30 days before grafting in order to promote activity.

In experiment 6 , the ortets with the best and worst performances in experiment 5 (early evaluated by visual signs of decay) were assayed. Additionally, two adult genotypes corresponding to an extremely rare fastigiated
Table 2. Genotypes used as scions donors in the grafting experiments.

Genotipos utilizados como dadores de púas en los experimentos de injertado.

\begin{tabular}{llll}
\hline Denomination & Provenance & \multicolumn{1}{c}{ Sex } & Experiment \\
\hline O1 & Cerro Otto & Female & 5,7 \\
O2 & Cerro Otto & Male & 5,7 \\
O3 & Cerro Otto & Juvenile & 5,7 \\
O4 & Cerro Otto & Female & 5,7 \\
O5 & Cerro Otto & Female & 5,7 \\
O6 & Cerro Otto & Juvenile & 5,7 \\
O7 & Cerro Otto & Female & 5,7 \\
SR10 & San Ramón & Female & 5,7 \\
SR11 & San Ramón & Male & 5,7 \\
SR12 & San Ramón & Female & $5,7,6$ \\
SR13 & San Ramón & Female & 5,7 \\
SR7 & San Ramón & Male & 5,7 \\
SR8 & San Ramón & Male & $5,7,6$ \\
SR9 & San Ramón & Male & 5,7 \\
F1AV & Río Traful & Male & 6 \\
F2LM & Cerro Otto & Male & 6 \\
\hline
\end{tabular}

variety of patagonian cypress, denominated A. chilensis $\mathrm{f}$. stricta nov. form. (Havrylenko 1965) were included. An individual plot layout was used, with 18 (ortet SR12), 21 (ortet SR8), 11 (ortet F1AV) and 42 (ortet F2LM) replicates. All grafts were practiced using provenance $\mathrm{P}$ seedlings as rootstock. 
Apical cleft grafting was applied in all three experiments. Scion and rootstock were tied together using rubber grafting tapes, and a contact sealing fungicide was applied covering the unions. Plastic bags were placed over the grafts to keep up humidity. Systemic fungicide was applied to the rootstock each 15 days starting three weeks after grafting. Plastic bags were partially opened two months after grafting, and completely removed one month later.

Survival was evaluated during the growing season following each experiment. Scions vegetative growth resume was the criteria to determine graft success. Data were analyzed using the generalized linear model with GENMOD procedure in SAS 8.0 (SAS Institute Inc., Cary, N.C., USA), testing the null hypothesis that the response variable graft success (binomial response), was independent of scion and rootstock provenances and of scion type, when corresponding.

The provenances used as scions and rootstock were selected encompassing the entire rain gradient, and the combinations between scion and rootstock were selected in order to avoid genetic relationships between both grafted genotypes; thus augmenting the probability of incompatibilities. The main geographic characteristics of the populations used for all the rooting and grafting experiments are shown in table 3 .

\section{RESULTS}

Stem cuttings. Percentage of rooting was very low in all the four experiments, and therefore no statistical analysis on the results was applicable. On a total of 1,469 assayed cuttings from adult genotypes, only four produced adventitious roots $(0.27 \%)$, and corresponded to the xeric-provenance genotypes SR1 (late summer experiment, $5,600 \mathrm{mg} \mathrm{L}^{-1}$ IBA level), SR4 (late spring experiment, 4,200 and 7,000 $\mathrm{mg} \mathrm{L}^{-1}$ IBA levels) and SR5 (late spring experiment, 7,000 $\mathrm{mg} \mathrm{L}^{-1}$ IBA level). For the juvenile genetic entities, percent of rooting was also very low, with eight rooted cuttings on a total of $370(2.10 \%)$. Only one treatment, P12 progeny (multi-stemmed mother), produced remarkable results: in mid-summer experiment, $33.33 \%$ (5 on 15) of rooting was obtained, at $5,000 \mathrm{mg} \mathrm{L}^{-1}$ IBA level. The same progeny produced also two rooted cuttings $(13.33 \%)$ with the NAA gel treatment in the same experiment. Only one cutting corresponding to a non-xeric provenance (juvenile seedlings from B provenance) rooted (late winter experiment, 7,000 $\mathrm{mg} \mathrm{L}^{-1}$ IBA level). No positive responses were obtained in the control plots $\left(0 \mathrm{mg} \mathrm{L}^{-1}\right.$ IBA level).

Grafting. Early spring was found to be the most adequate season for apical cleft grafting in A. chilensis. After one year, $80.95 \%$ (34 on 42) of the practiced grafts succeeded in experiment 5 . Grafting success was significantly different according to scion type $\left(\chi^{2}=10.11 ; P=0.0064\right)$ : type 1 scions (hardwood) had only $37.50 \%$ of success, while types 2 (semi-hardwood) and 3 (semi-herbaceous) showed $92.85 \%$ and $90.00 \%$ of successful grafts respectively. Success was independent of rootstock and scion provenances, indicating a wide compatibility among genotypes from the different origins. Only genotype SR8 did not produce any successful graft in this experiment. All the practiced grafts showed callus formation in early-spring experiment.

In experiment 6 (mid-spring) percentage of graft success was very low, with an average of $6.52 \%$ (6 on a total of 92). Positive responses corresponded to: genotype SR12 (1 on 18); genotype F1AV (1 on 11); and F2LM (4 on 42). Genotype SR8 did not produce any successful graft.

In opposition to early-spring results, no positive results were obtained in experiment 7 , suggesting that late summer is not favorable for A. chilensis propagation by apical cleft grafting. Callus formation was not observed in this experiment.

\section{DISCUSSION}

Genetic variation in rooting ability. Typically, the capacity of producing adventitious roots from stems is related to several natural adaptations of species (i.e. latent root

Table 3. Provenances used in the rooting and grafting experiments; m.a.p.: mean annual precipitation.

Procedencias utilizadas en los ensayos de enraizado e injertado; m.a.p.: precipitación media anual.

\begin{tabular}{lccccc}
\hline Provenance & Forest type & Latitude S & Longitude W & m.a.p. (mm) & Material \\
\hline Puerto Blest & Humid & $41^{\circ} 01^{\prime}$ & $71^{\circ} 49^{\prime}$ & 2,650 & Rootstock / cuttings \\
Río Traful & Mesic & $40^{\circ} 39^{\prime}$ & $71^{\circ} 15^{\prime}$ & 955 & Scions \\
Cerro Leones & Mesic & $41^{\circ} 04^{\prime}$ & $71^{\circ} 09^{\prime}$ & 800 & Rootstock \\
Cerro Otto & Mesic & $41^{\circ} 05^{\prime}$ & $71^{\circ} 19^{\prime}$ & 900 & Scions / cuttings \\
Huinganco & Xeric & $37^{\circ} 08^{\prime}$ & $70^{\circ} 36^{\prime}$ & 604 & Cuttings \\
San Ramón & Xeric & $41^{\circ} 00^{\prime}$ & $71^{\circ} 05^{\prime}$ & 500 & Scions \\
Pilcañeu & Xeric & $41^{\circ} 13^{\prime}$ & $70^{\circ} 42^{\prime}$ & 330 & Rootstock / cuttings \\
El Maitén & Xeric & $42^{\circ} 02^{\prime}$ & $71^{\circ} 12^{\prime}$ & 586 & Cuttings \\
\hline
\end{tabular}


initials, epicormic buds, root sprouting, stem adventitious roots) to propagate by vegetative means in their evolutive habitats. The three genetically related Cupressaceae species from the subantarctic forest of South America, Fitzroya cupressoides (Molina) I. M. Johnst., Pilgerodendron uviferum (D. Don) Florin, and Austrocedrus chilensis (D. Don) Pic. Ser. et Bizzarri, have evolved propagation strategies that, as in most conifers, rely almost exclusively on sexual reproduction. Notwithstanding, the three species have also developed complementary mechanisms of vegetative propagation, with more or less incidence in their stand regeneration dynamics. Probably, these adaptive clonal mechanisms allow the species to occupy very specific and stable environmental niches, without the need of genetic variation (Geneve 2006). In F. cupressoides (Veblen and Ashton 1982) and P. uviferum (Rovere et al. 2004), vegetative reproduction by branch layering is an important adaptation to humid and bad-drained soils, in which clonal stand structures are common.

In A. chilensis, natural vegetative propagation by branch layering is also observed (Gallo et al. 2004). Although there is no specific environmental situation in which it becomes the predominant way of reproduction, the relative frequency of clonal phenotypes is higher in the xeric marginal-extreme populations, suggesting an adaptive value for natural rooting capacity. Although no statistical analyses could be performed for the genetic factors assayed in this work, it must be pointed out that $91.6 \%$ (11 on 12) of the positive responses corresponded to xeric genotypes. Despite the limitations of our experimental design, one derived hypothesis from these results is that in the extremely adverse xeric environment of the ecotone between the subantarctic forest and the patagonian steppe, clonal reproduction is an adaptation that complements a highly fluctuating and climate-dependent seed regeneration. The competitive advantage of the multi-stemmed phenotypes (Pastorino and Gallo, 1997) would be larger in the xeric than in the mesic and humid provenances, and therefore the genotypic frequencies of individuals with natural rooting ability would be higher. Further research to precisely test this hypothesis is needed.

Results found for the juvenile cuttings of P12 progeny (multi-stemmed mother genotype), 33\% of rooted cuttings in mid-summer experiment, suggest that there are genotypes with a relatively high intrinsic rooting capacity, which can be improved given the appropriate conditions for rooting.

Environmental factors and ontogenetic stage affecting rooting ability. According to Hartmann et al. (2002), when rooting narrow-leaved evergreens, best results are expected if cuttings are collected during late fall to late winter (dormant or cessation periods of growth). Nevertheless, the results could be variable even among closely related species. Scarce antecedents have been reported for species genetically related to A. chilensis in relation to the optimal season of cutting collection. The related Cupressaceae species from Oceania, Libocedrus spp. and Papuacedrus papuana (F. Muell.) H. L. Li, can eventually be propagated by cuttings taken during summer ${ }^{1}$. For $P$. uviferum, the most closely related to A. chilensis species, a relatively good rooting ability was found when using vegetative material collected between fall and spring (Rovere et al. 2004), although no contrasting summer experiments were reported.

Despite the poor general performance for rooting obtained in this work, an apparent tendency was observed in relation to the season of cutting collection. In the winter experiment with juvenile ortets, only one cutting rooted on a total of $230(0.43 \%)$, while in mid-summer experiment, seven juvenile cuttings rooted on a total of $150(4.66 \%)$. Moreover, three of the four rooted adult cuttings were obtained in the late-spring experiment. These results could be indicating that although A. chilensis would be a hard-to-root species even in juvenile stages, the activity period would be more favorable for adventitious root formation.

In difficult-to-root woody species, the ease of adventitious root formation tends to decline with the physiological age of the stock plants, due to several progressive changes in morphological, anatomical and biochemical traits (Hartmann et al. 2002). The mentioned behavior of P12 progeny (33\% of rooting ability), composed of 10 openpollinated five year old seedlings, resulted contrasting to all the other treatments, probably indicating that ontogeny results crucial in determining the rooting capacity of $A$. chilensis. In relation to the supply of exogenous auxins, the fact that none of the control cuttings ( 0 on 289) in any of the experiments produced roots, and that the 10 rooted cuttings within the IBA plots corresponded to doses between 4,200 and 7,000 $\mathrm{mg} \mathrm{L}^{-1}$, could be indicating that higher levels of exogenous auxins are needed to promote rooting. In general, the more lignified the vegetative material, the higher the hormone doses applied should be (Hartmann et al. 2002). In this work, the cuttings taken from San Ramón population (ca. 100 year old trees) were in general harder than those from Cerro Otto (ca. 40 year old trees). Nevertheless, the only positive results among the adult genotypes were from San Ramón.

In future experiments, juvenile (seedlings) or rejuvenated (grafted or hedged plants) material should be used in order to precisely study the genetic variation in rooting ability for A. chilensis. Studies with hypocotyl cuttings have been developed in conifers (Greenwood and Weir 1994), and could be a useful approach in order to avoid the effect of age, using progenies as cutting donors. More research is necessary to study also the influence of the environmental factors on the rooting process and to adjust practical methodologies. Higher doses of auxins should be assayed in experiments with larger plot sizes.

\footnotetext{
1 Trevor Hinchliffe. 2007. Vegetative propagation of Cupressaceae species from Oceania. Terra Flora Landscape Services. NSW, Australia. pers. com. (electronic mail).
} 
Grafting. It is widely accepted that in plants, grafts made between genetically related individuals are more likely to be successful than those between unrelated genotypes. In conifers, notably in Pseudotsuga menziesii (Mirb.) Franco (Copes 1969, 1999), incompatibility problems are common. Results obtained in this work indicated that compatibility between scion and rootstock from different populations (i.e. genetically unrelated) of A. chilensis would be wide, which enhances the probabilities of obtaining good results with low costs for breeding programs. Genotype SR8, used as one of the scions donors in this work, probably deserves special genetic study because of its behavior in failing all the practiced grafts. Several genetically determined mechanisms are known to cause incompatibilities, such as poor phloem differentiation from callus cells due to lack of hormones or carbohydrates. The success of grafting is primarily determined by the capacity of producing parenchymatous callus tissue in response to wounding. This process is dependent on the genetics and on a number of environmental factors, among which the season of grafting in relation to scion and rootstock activity and to growth regulators action is one of the most relevant.

According to Hartmann et al. (2002), many conifers are grafted successfully during late winter to spring. In this work, early spring was found to be the most appropriate time for scion collection and grafting, with activity of both scion and rootstock recently initiated. Callus proliferation, process that is essential for graft union, was observed in all the 42 grafts practiced in the early spring experiment, in which $81 \%$ of successful grafts were obtained. On the contrary, none of the grafts practiced in the late summer experiment produced callus. These extreme responses to wounding (early versus late growing season) could be indicating that the auxin gradients that are involved in the callusing process (Hartmann et al. 2002) diminish rapidly during the activity period in A. chilensis.

Scion stem tissue consistence, in relation to season of grafting, was found to be an important factor affecting grafting success. Scions with better performances were semi-hardwood stems, with vigorous shoots and long internodes from the current growing season. The higher rate of failure of hardwood scions, with compact foliage and short internodes, can be attributable in part to anatomical mismatching due to sinuosity and hardness of the stems. Although no other grafting method was assayed in this work, the apical cleft grafting was found to be adequate in relation to the growth activity of both scions and rootstock in early-spring. Grafting methods in which the top of the rootstock is completely removed are usually dependent on a moderate activity of the rootstock (Hartmann et al. 2002) and the phenological stage of the scion donor plant is equally determinant of success. In the adult male individuals used as ortet in our early-spring experiment, pollen aments were recently developed at the moment of scions collection. This phenological stage could be used as a practical indicator of a favorable time for grafting in A. chilensis.

\section{CONCLUSIONS}

Austrocedrus chilensis is a hard-to-root species. Genetic variation for rooting ability as an adaptive trait deserves more research. Probably, the most genetically variable and endangered xeric marginal populations have relatively higher frequencies of genotypes with natural rooting ability, which would be an advantage for conservation and breeding objectives, once the environmental factors affecting the rooting process are optimized. It is likely that acceptable rooting percentages can be achieved for certain genotypes when using juvenile or rejuvenated material, and higher exogenous auxin doses. Grafting capacity of A. chilensis was high, and compatibility among genotypes was wide enough to assure good results at low costs. The optimal season for apical-cleft grafting was early spring in north Patagonia. Several objectives of present and future research programs could be enhanced using vegetative propagation of A. chilensis by scion grafting. Rescue of genotypes from the extreme-marginal populations, the most genetically diverse and endangered, should be a priority for conservation of the genetic resources of the species, as well as for other rare genotypes such as the fastigiated variety, that counts with less than 10 known individuals in the wild. Grafting could also be useful to study the transference and the genetic resistance of a widespread disease, locally known as "cypress decay".

\section{ACKNOWLEDGEMENTS}

This work was developed with the financial support of the Agencia Nacional de Promoción Científica y Tecnológica (ANPCyT), through the project PICT 12422, "Mejoramiento Genético de Ciprés de la Cordillera como alternativa productiva para la Precordillera Nordpatagónica".

\section{REFERENCES}

Atangana AR, Z Tchoundjeu, EK Asaah, AJ Simons, DP Khasa. 2006. Domestication of Allanblackia floribunda: Amenability to vegetative propagation. Forest Ecology and Management 237: 246-251.

Bran D, A Pérez, D Barrios, M Pastorino, J Ayesa. 2003. Mapa de distribución del "Ciprés de la Cordillera". Fundación Vida Silvestre Argentina, Bosques y Selvas. Accessed Jul. 10, 2005. Available in http://www.vidasilvstre.org.ar/

Conifer Specialist Group. 1998. Austrocedrus chilensis. In IUCN 2007, 2007 IUCN Red List of Threatened Species. Accessed Nov 25, 2007. Available in http://www.iucnredlist.org/ .

Copes DL. 1969. Graft union formation in Douglas-fir. American Journal of Botany 56 (3): 285-289. 
Copes DL. 1999. Breeding graft-compatible Douglas-fir rootstocks (Pseudotsuga menziesii (Mirb.) Franco). Silvae Genetica 48 (3-4): 188-193.

Dick JMcP, H Bisset, C McBeath. 1996. Provenance variation in rooting ability of Calliandra calothyrsus. Forest Ecology and Management 87: 175-184.

Donoso C, L Gallo. 2004. Aspectos conceptuales y metodológicos. In Donoso C, A Premoli, L Gallo, R Ipinza eds. Variación intraespecífica en las especies arbóreas de los bosques templados de Chile y Argentina. Santiago, Chile. Editorial Universitaria. p. 23-37.

Donoso C, B Escobar, M Pastorino, L Gallo, J Aguayo. 2006. Autoecología de las especies. Coníferas chilenas (Gimnospermas). In Donoso Zegers C ed. Las especies arbóreas de los bosques templados de Chile y Argentina. Autoecología. Valdivia, Chile. Marisa Cuneo Ediciones. p. 54-67.

Gallo LA, MJ Pastorino, C Donoso. 2004. Variación en Austrocedrus chilensis (D.Don) Pic. Ser. et Bizzarri (Ciprés de la Cordillera). In Donoso C, A Premoli, L Gallo, R Ipinza eds. Variación intraespecífica en las especies arbóreas de los bosques templados de Chile y Argentina. Santiago, Chile. Editorial Universitaria. p. 233-251.

Geneve RL. 2006. Alternative strategies for clonal plant reproduction. Combined Proceedings of the International Plant Propagators Society 56: 269-273.

Gómez Hernández CP. 1994. Propagación vegetativa de: Austrocedrus chilensis (D. Don) Pic. Ser. et Bizz. (ciprés de la cordillera); Prumnopitys andina (Poepp. ex Endl.) de Laub. (lleuque); Eucryphia glutinosa (Poepp. et Endl.) Baillon (guindo santo) y Orites myrtoidea (P. et E.) B. et $\mathrm{H}$. ex Sleumer (radal enano); mediante enraizamiento de estacas. Professional practice report, Biologist degree. Concepción, Chile. Facultad de Ciencias Naturales y Oceanográficas, Universidad de Concepción. 77 p.

Greenwood MS, RJ Weir. 1994. Genetic variation in rooting ability of loblolly pine cuttings: effects of auxin and family on rooting by hypocotyl cuttings. Tree Physiology 15: 41-45.

Hartmann HT, DE Kester, FT Davies Jr, RL Geneve. 2002. Plant Propagation: Principles and Practices. New Jersey, USA. Prentice Hall. 880 p.

Havrylenko D. 1965. Contribución dendrológica al conocimiento del ciprés de la cordillera Austrocedrus chilensis (Don) Florin et Boutel. Revista Forestal Argentina 9(3): 78-80.

Hechenleitner VP, MF Gardner, PI Thomas, C Echeverría, B Escobar, P Brownless, AC Martínez. 2005. Plantas Amenazadas del Centro-Sur de Chile. Distribución, Conservación y Propagación. Valdivia, Chile. Universidad Austral de Chile y Real Jardín Botánico de Edimburgo. 188 p.

Hinesley LE, FA Blazich, LK Snelling. 1994. Propagation of Atlantic white cedar by stem cuttings. Horticultural Science 29: 217-219.

IPCC. 2008. Climate Change and Water. Intergovernmental Panel on Climate Change technical paper VI. In Bates, Kundzewicz BC, ZW, Wu S, Palutikof JP eds. IPCC Secretariat. Geneva, Switzerland. 210 p.

Leakey RRB, Z Tchoundjeu, K Schreckenberg, SE Shackleton, CM Shackleton. 2005. Agroforestry tree products (AFTPs): targeting poverty reduction and enhanced livelihoods. Int. J. Agric. Sustain. 3: 1-23.
Littell RC, GA Milliken, WW Stroup, RD Wolfinger, O Schabenberger. 2006. Chapter 8: Random Coefficient Models. In SAS for Mixed Models, Second Edition, SAS Institute Inc. Cary, NC, USA. p. 317-341.

Martínez Crovetto R. 1948. Notas sobre plantas indígenas cultivadas en la Argentina. Revista de Investigaciones Agrícolas 2 (3): 105-116.

Mesén F. 1998. Enraizamiento de estacas juveniles de especies forestales: uso de propagadores de sub-irrigación. Turrialba, Costa Rica. Serie Técnica. 36 p. Manual Técnico/CATIE $\mathrm{n}^{\mathrm{o}} 30$.

Park YS, JM Bonga, TJ Mullin. 1989. Clonal Forestry. In Mandal AK, GL Gibson eds. Forest Genetics and Tree Breeding. New Delhi, India. CBS Publishers and Distributors. p. 143-167.

Pastorino MJ. 2001. Genetic Variation and Reproduction System of Austrocedrus chilensis (D. Don) Florin et Boutelje, a cypress endemic to the Andean-Patagonian Forest. Ph.D. Thesis. Göttingen, Germany. University of Göttingen. 165 p.

Pastorino MJ, LA Gallo. 1997. Natural vegetative propagation of Austrocedrus chilensis (Cupressaceae) in marginal populations. II Southern Connection Congress, Southern temperate biota and ecosystems, past, present and future: proceedings. Valdivia, Chile. Universidad de Chile y Universidad Austral de Chile. p. 178.

Pastorino MJ, LA Gallo, HH Hattemer. 2004. Genetic variation in natural populations of Austrocedrus chilensis, a cypress of the Andean-Patagonian Forest. Biochemical Systematics and Ecology 32: 998-1008.

Pastorino MJ, MM Fariña, D Bran, LA Gallo. 2006. Extremos geográficos de la distribución natural de Austrocedrus chilensis (Cupressaceae). Bol. Soc. Argentina de Botánica 41 (3-4): 307-311.

Rovere AE, AC Premoli, JC Aravena, A Lara. 2004. Variación en Pilgerodendron uviferum (D. Don) Florin (Ciprés de las Guaitecas). In Donoso C, A Premoli, L Gallo, R Ipinza eds. Variación intraespecífica en las especies arbóreas de los bosques templados de Chile y Argentina. Santiago, Chile. Editorial Universitaria. p. 253-275.

SAGPyA. 2008. Boletín precios forestales, Marzo de 2008. Accessed Nov. 25, 2008. Available in http://www.sagpya. mecon.gov.ar/

Schmaltz J. 1992. La reconquista de la estepa por el bosque de ciprés. Descripción de un caso estudiado, primer informe. Esquel, Argentina. CIEFAP-GTZ. 6 p. Publicación Técnica 11.

Shoemake LJ, MA Arnold, Davies FTJr. 2004. Provenance impacts transplant establishment and adventitious root regeneration of Sycamore. Journal of the American Society of Horticultural Science 129 (3): 360-367.

Stankova T, K Panetsos. 1997. Vegetative propagation of Cupressus sempervirens $\mathrm{L}$. of Cretan origin by softwood cuttings. Silvae Genetica 46(2-3): 137-144.

Tchoundjeu Z, ML Ngo Mpecka, E Asaaha, A Amougoub. 2004. The role of vegetative propagation in the domestication of Pausinystalia johimbe (K. Schum), a highly threatened medicinal species of West and Central Africa. Forest Ecology and Management 188: 175-183.

Veblen TT, DH Ashton. 1982. The regeneration status of Fitroya cupressoides in the Cordillera Pelada, Chile. Biological Conservation 23: 141-161. 
Wollemi Pine International. 2004. Accessed Jun. 25, 2007. Available in http://www.wollemipine.com/ .

Wright JW. 1976. Introduction to Forest Genetics. New York, USA. Academic Press. 463 p.

Ying CH, WT Bagley. 1977. Variation in rooting capability of Populus deltoides. Silvae Genetica 26(5-6): 204-207.
Zobel DB. 1990. Chamaecyparis lawsoniana (A. Murr.) Parl., Port-Orford-Cedar. In Burns RM, BH Honkala eds. Silvics of North America: 1. Conifers. Agriculture Handbook 654. Washington DC, USA. USDA Forest Service. p. 155-170.

Zobel B, J Talbert. 1984. Applied forest tree improvement. Illinois, USA. Waveland Press. 505 p.

Recibido: 25.01 .08

Aceptado: 02.01.09 